\title{
Entrevista: Paul Singer
}

Nesta entrevista realizada por e-mail em 12 de setembro de 2003, Paul Israel Singer - que está à frente da Secretaria Nacional de Economia Solidária (Senaes) do Ministério do Trabalho e Emprego - falou a Fábio de Oliveira e Tatiana Freitas Stockler das Neves de seu percurso intelectual e do papel da Universidade e do Estado para o desenvolvimento da Economia Solidária.

Cadernos - Atualmente você trabalha com a temática da economia solidária. Antes disso você trabalhou com quais temas? Como foi esse percurso?

Paul Singer - Ao longo de minha vida profissional e militante ocupei-me de diversos temas: desenvolvimento econômico e seus desdobramentos territoriais, que foi o tema de minha tese de doutoramento (Singer, 1966); dinâmica populacional e desenvolvimento, que se tornou o tema de minha tese de livre-docência (Singer, 1968) e trabalho e desemprego, que foi minha preocupação principal nos anos 1970, quando publiquei Economia política do trabalho (Singer, 1977). Mas me ocupei também da economia dos serviços, tema que me chamou a atenção quando investiguei a mudança na estrutura da ocupação. Em função disso, estudei os serviços de saúde, do que resultou Prevenir e curar, o livro que coordenei (Singer, Campos \& Oliveira, 1978). A partir dos 1980, minha preocupação principal foi a globalização, que se tornou o tema de meus cursos de pós-graduação, quando voltei à universidade em 1993, após ter ficado fora dela por quatro anos como secretário municipal de planejamento. $\mathrm{O}$ agravamento do desemprego me fez voltar à questão do trabalho, o que a partir de 1996 me levou à economia solidária.

Cadernos - Muitos de seus livros demonstram um esforço em aproximar a linguagem da economia à linguagem do senso comum, como uma clara tentativa de romper com o "economês", que, entendemos, visa permitir que as pessoas dominem a economia. Por outro lado, assistimos no Brasil, a colonização da vida cotidiana pelos "imperativos" econômicos: por exemplo, hoje, qualquer pessoa é obrigada a preocupar-se com a taxa Selic, com a bolsa de valores de Nova Iorque e vê crescer o número de programas televisivos dedicados exclusivamente à economia. Afinal, são as pessoas que vão dominar a economia ou a economia é que vai dominar as pessoas?

Paul Singer - Acho que a economia ficou muito mais instável e agressiva para as pessoas depois que o neo-liberalismo se tornou hegemônico, nos anos 1990, no Brasil. O desemprego em massa e de longa duração é o conhecido "horror econômico", que desgraça a vida de muita gente, o que deixa todo mundo angustiado. Para que as pessoas possam voltar a dominar a economia em vez de serem dominadas por ela é preciso que elejam governos dispostos a controlar as forças de mercado, em vez de se submeter passivamente a elas. A principal força de mercado é a intermediação privada de capitais, que, fora de controle, se torna um elemento parasitário, que se enriquece com a instabilidade econômica. 
Cadernos - É possível construir, pensando de um modo geral, uma economia solidária no contexto de uma sociedade capitalista? Quais os grandes desafios que se apresentam para essa construção?

Paul Singer - A economia solidária de fato se constrói nos interstícios que as crises inerentes ao capitalismo deixa desocupados. São empresas em crise "tomadas" pelos seus empregados e transformadas em cooperativas; terra deixada improdutiva que via reforma agrária é entregue a trabalhadores, que a cultivam em empreendimentos solidários; é o lixo que infesta as cidades que é reciclado por cooperativas de catadores etc. O maior desafio é motivar e resgatar a multidão deixada à margem, fazendo-a ver que sua emancipação é possível desde que se tornem os protagonistas dela.

Cadernos - Tomando por base, agora especificamente, as experiências no Brasil em relação à construção de cooperativas como as de catadores de papel, de artesãos etc., ou seja, as que envolvem pessoas em situação de extrema pobreza, você considera que essas cooperativas têm o potencial de gerar renda suficiente para a manutenção da vida com dignidade? Se é possível, o que é preciso garantir para que esse objetivo seja alcançado?

Paul Singer - No caso específico dos catadores, eles só poderão alcançar renda digna se puderem dominar as etapas subseqüentes à catação: separação, compressão, reprocessamento dos materiais, produção de novos bens. Os catadores terão de se organizar para exigir e conquistar uma política ambientalista e social por parte das autoridades municipais.

Cadernos - Em sua avaliação, existe alguma diferença de inserção determinada pela questão de gênero nas iniciativas de construção de cooperativas? Se existe, de que modo podemos compreender isso?

Paul Singer - Acho que não existe diferença de inserção em função do gênero, mas conjunturalmente homens e mulheres são afetados de maneira distinta pela crise. A desindustrialização atingiu mais os homens, a expansão dos serviços abriu novas oportunidades às mulheres. Mas, acho que em breve as distinções de gênero na inserção social vão começar a desaparecer, pois há cada vez menos trabalhos que somente um gênero pode executar.

Cadernos - Qual o papel das universidades na construção da economia solidária?

Paul Singer - As universidades abrigam e apoiam incubadoras de cooperativas populares, que constituem elo vivo entre a comunidade acadêmica e as camadas destituídas. A partir das experiências das incubadoras, desenvolvem-se a pesquisa e o ensino de economia solidária, tanto para forjar a teoria desse processo, como para formar os quadros capacitados a levá-lo adiante. 
Cadernos - Como formular políticas públicas que incentivem a economia solidária e ao mesmo tempo não sejam uma imposição de cima para baixo de práticas que deveriam ser pautadas pela autogestão e pela iniciativa das próprias pessoas?

Paul Singer - Há de fato o perigo de políticas públicas tentarem construir a economia solidária a partir do Estado, o que a torna odiosa aos que são coagidos a integrá-la. A autogestão para ser autêntica tem de ser o produto da conviç̧ão de quem a pratica. Políticas públicas devem oferecer o suporte material aos movimentos e ONGs, que prestam um serviço público ao difundir a economia solidária, especialmente entre os que podem ser redimidos por ela.

Cadernos - Como a economia solidária se insere no atual governo federal e quais ações serão implementadas?

Paul Singer - O governo federal instituiu a Secretaria Nacional de Economia Solidária no Ministério do Trabalho e Emprego, que tem por objetivos fomentar empreendimentos solidários, apoiar agências que se dedicam a esse mister e divulgar dados e análises da situação em que se encontra a economia solidária no país e no exterior. Muitos outros órgãos do governo tomam o desenvolvimento da economia solidária como premissa de suas próprias políticas públicas. Estão nesse caso os ministérios de Segurança Alimentar, Meio Ambiente, Desenvolvimento Agrário, Minas e Energia, Cidades etc.

\section{Referências Bibliográficas}

Singer, P. I. (1966). Desenvolvimento econômico sob o prisma da evolução urbana. Tese de doutorado, Faculdade de Filosofia, Letras e Ciências Humanas, Universidade de São Paulo, São Paulo.

Singer, P. I. (1968). Papel do crescimento populacional no desenvolvimento econômico. Tese de livre docência, Faculdade de Saúde Pública, Universidade de São Paulo, São Paulo.

Singer, P. I. (1977). Economia política do trabalho. São Paulo: Hucitec.

Singer, P. I., Campos, O. \& Oliveira, E. M. (1978). Prevenir e curar: o controle social através dos serviços de saúde. Rio de Janeiro: Forense Universitária. 